\title{
Fat Mass and Obesity Associated Gene Variants Are Associated With Increased Growth Hormone Levels and Affect Glucose and Lipid Metabolism in Lean Women
}

\author{
P. LUKÁŠOVÁ ${ }^{1}$, M. VAŇKOVÁ ${ }^{1}$, J. VČELÁK ${ }^{1}$, D. VEJRAŽKOVÁ ${ }^{1}$, O. BRADNOVÁ ${ }^{1}$, \\ S. STANICKÁ ${ }^{1}$, V. HAINER ${ }^{1}$, B. BENDLOVÁ ${ }^{1}$ \\ ${ }^{1}$ Department of Molecular Endocrinology, Institute of Endocrinology, Prague, Czech Republic
}

Received June 2, 2015

Accepted June 16, 2015

\section{Summary}

First intron variability of the fat mass and obesity associated gene (FTO) has strong impact on adiposity. We focused on lean women carrying the most "obesity-risk" haplotype to study their anthropometric parameters and hormonal and metabolic profile. Genotype-phenotype correlation was performed in a group of 172 lean women (body mass index (BMI) $\geq 18.5$ and $<25 \mathrm{~kg} / \mathrm{m}^{2}$; age $26.8 \pm 7.26$ years), 77 of them used hormonal contraceptives. Even in lean women the association of the risk haplotype CAGA with BMI was confirmed but it did not influence the anthropometric indices of body composition. CAGA carriers compared to non-carriers had significantly higher both fasting $(p=0.016)$ and post glucose load $(p<0.001)$ levels of growth hormone (GH), significantly higher glucose, insulin and C-peptide levels in the late phase of oGTT and lower fasting concentration of total cholesterol and LDL-cholesterol. Administration of hormonal contraceptives further increased observed hormonal and metabolic effects in CAGA carriers. We conclude that higher levels of $\mathrm{GH}$ in lean women carrying the FTO "obesity risk" haplotype could protect them from the development of obesity. The relation between the FTO gene variability and GH secretion has to be elucidated. This is the first study demonstrating the interaction of FTO genotype with hormonal contraception.

\section{Key words}

Fat mass and obesity associated gene • Gene variants • Glucose metabolism • Growth hormone • Hormonal contraception

\section{Corresponding author}

P. Lukášová, Department of Molecular Endocrinology, Institute of Endocrinology, Národní 8, 11694 Prague 1, Czech Republic. Fax: +420 224905 325. E-mail: plukasova@endo.cz

\section{Introduction}

Genome-wide association studies have led to the identification of a number of candidate genes related to worldwide diseases such as type 2 diabetes mellitus or obesity and polycystic ovary syndrome. In 2007, the fat mass and obesity associated gene (FTO) was identified as a gene with strong obesity-related traits. Several independent laboratories detected a range of single nucleotide polymorphisms (SNPs) in the first intron of the gene with a great impact on adiposity (Dina et al. 2007, Frayling et al. 2007, Scuteri et al. 2007). Consequently, the association of the FTO gene with obesity was confirmed in various populations around the world. Through its association with obesity, FTO was also confirmed as a susceptibility gene for diabetes mellitus type 2 (DM2) (Frayling et al. 2007, Scott et al. 2007) and polycystic ovary syndrome (PCOS) (Attaoua et al. 2008, Barber et al. 2008). However, the effects of these intronic variants on FTO function are still unclear.

FTO is a member of the AlkB-related nonheme iron- and 2-oxoglutarate-dependent dioxygenase family. Studies in mice suggest that it may be involved in nucleic acid demethylation (Gerken et al. 2007, Sanchez-Pulido and Andrade-Navarro 2007) and that it functions as a transcriptional coactivator playing a role in the epigenetic regulation of the development and maintenance of fat tissue (Gerken et al. 2007).

The FTO gene (16q12.2) is widely expressed in a variety of human tissues, with the highest levels in the brain, particularly in hypothalamic nuclei, a 
well-defined key regulatory centre of energy homeostasis (Dina et al. 2007, Frayling et al. 2007). Its mRNA level is regulated by the energy balance in response to feeding or fasting (Gerken et al. 2007, Frederiksson et al. 2008). The association of FTO gene variants with cerebrocortical insulin resistance typical for obese humans was documented as well (Tschritter et al. 2007).

FTO is also expressed in pancreatic islets, skeletal muscle, in liver as well as in adipose tissue (Dina et al. 2007, Grunnet et al. 2009). The expression of FTO in adipose tissue was usually higher in obese individuals. The role of FTO in peripheral fat lipolysis by which the gene could affect the body weight regulation was also reported (Wåhlén et al. 2008). The study of skeletal muscle biopsies revealed increased energy efficiency and potentially increased mitochondrial coupling in risk allele (rs9939609, intron 1) carriers vs. non-carriers which may contribute to the increased risk of obesity and DM2 (Grunnet et al. 2009). However, FTO genotype did not influence the mRNA expression either in skeletal muscle or in adipose tissue (Wåhlén et al. 2008, Grunnet et al. 2009).

In our previous study which included 1388 Czech adults of Caucasian origin an association of 4 SNPs in the $1^{\text {st }}$ intron of FTO gene with BMI $(p<0.001)$, waist circumference $(p<0.001)$ as well as with leptin level $(\mathrm{p}=0.003)$ and glucose levels at the $60^{\text {th }}, 90^{\text {th }}$ and $120^{\text {th }}$ min of the oGTT $(\mathrm{p}<0.005)$ was confirmed (Vcelak et al. 2008). In this study we focused on a group of lean healthy control women to evaluate the associations of the most risk haplotype CAGA with anthropometric data, parameters of glucose and lipid metabolism, selected hormones and adipokines. We also studied the possible role of interaction of the genotype with hormonal contraception which has been underestimated until now.

\section{Materials and Methods}

\section{Subjects characteristics}

Our study cohort consisted of 172 lean $\left(\mathrm{BMI} \geq 18.5\right.$ and $<25 \mathrm{~kg} / \mathrm{m}^{2}$ ) healthy women carrying combinations of two major FTO haplotypes TGTT and CAGA (BMI $21.5 \pm 1.99 \mathrm{~kg} / \mathrm{m}^{2}$; age $26.8 \pm 7.26$ years). Subjects with family history of DM2, gestational diabetes, PCOS and impaired fasting glucose or impaired glucose tolerance were excluded from the study. Seventy-seven women used hormonal contraceptives (HC): $52 \%$ women used low-dose oral contraceptives (OC; ethinylestradiol (EE) or estradiolvalerate (E2V) below $30 \mathrm{ug}$ ); $42 \%$ combined OC (with 30-35 ug EE and third-generation progestogens) and the remaining $6 \%$ contraceptive coil.

The protocol of the study was approved by the Ethic Committee of the Institute of Endocrinology and all subjects gave their informed consent.

\section{Anthropometric measurements}

Body weight, height, waist and hip circumference were measured in all subjects, body mass index (BMI) and waist-to-hip ratio (WHR) were calculated. To reflect the percentage of body fat we used body adiposity index (BAI, BAI $=[$ hip circumference/height $\left.{ }^{1.5}\right]$ - 18 [\%]) (Bergman et al. 2011).

\section{Metabolic and hormonal characteristics}

The baseline levels of glucose, C-peptide, immunoreactiv insulin, total cholesterol, high-density lipoprotein (HDL-) and low-density lipoprotein (LDL-) cholesterol, triglycerides and glycosylated hemoglobin $\left(\mathrm{HbA}_{1 \mathrm{c}}\right)$ [Cobas Integra, Roche Diagnostics], proinsulin [ELISA, DRG Diagnostics, Germany], glucagon [RIA, IBL], growth hormone $(\mathrm{GH})$ and insulin-like growth factor 1 (IGF-1) [IRMA, Immunotech], plasma renin activity (PRA) [RIA, Immunotech] and leptin [RIA, LINCO research] were assessed. Free fatty acids concentrations and their composition were measured by HPLC. All women underwent 3-h oral glucose tolerance test (oGTT) with $75 \mathrm{~g}$ glucose dose; during the test levels of glucose, C-peptide, insulin (in $30 \mathrm{~min}$ intervals), proinsulin, glucagon, free fatty acids (at 0 , $60^{\text {th }}, 180^{\text {th }} \mathrm{min}$ ) and growth hormone (at $0,60^{\text {th }}, 120^{\text {th }}$ min) were determined. Areas under the curves for glucose, C-peptide and insulin were calculated (AUC). To assess insulin sensitivity and beta-cell function, homeostasis models assessments (HOMA R and HOMA F, Matsuda index, Cederholm index and insulinogenic index) were used and derived disposition indices (betacell function*insulin sensitivity) were calculated (Matthews et al. 1985, Cederholm and Wibell 1990, Matsuda and DeFronzo 1999).

\section{Genotyping}

DNA was extracted from peripheral leukocytes using the commercial kit (QIAamp DNA Blood Kit, QIAGEN, Germany). The four intronic single nucleotide polymorphisms (SNPs), rs1421085 (T/C $)$, 
rs1121980 (G/A $)$, rs17817449 (T/G) and rs9939609 (T/A) in the FTO gene were assessed by ABI TaqMan SNP Genotyping Assays (LightCycler 480 System, Roche). Haplotype combinations were generated using a programme PHASE version 2.1. (http://stephenslab. uchicago.edu/software.html).

\section{Statistical analyses}

For statistical evaluation NCSS 2004 (Statistical Solutions, Saugus, USA) software was used. Data are given as means \pm SDs and as percentages. Data in Figures are shown as medians. The Chi-square test was used to assess deviation from Hardy-Weinberg equilibrium of the genotypic frequencies by calculating expected frequencies of genotype. Differences in biochemical and anthropometric data between subgroups were tested by non-parametric MannWhitney test, the two tailed $\mathrm{p}$ values $<0.05$ were considered to be significant.

\section{Results}

\section{FTO gene haplotypes}

The component obesity risk SNPs: rs142108 $(\mathrm{T} / \underline{\mathrm{C}}) ; \quad \operatorname{rs} 1121980 \quad(\mathrm{G} / \underline{\mathrm{A}}) ; \quad \operatorname{rs} 17817449 \quad(\mathrm{~T} / \underline{\mathrm{G}})$ and rs9939609 (T/A) are located within $19.6 \mathrm{~kb}$ region in intron 1 of the FTO gene and they are in linkage disequilibrium, however, programme PHASE generated 10 haplotype combinations in the cohort of our pilot study. For this study we selected 172 lean women carriers of two major haplotypes TGTT and CAGA $54(31.4 \%)$ were TGTT homozygotes; 78 were TGTT/CAGA heterozygotes $(45.3 \%)$ and 40 (23.3\%) were CAGA homozygotes.

Anthropometric and metabolic parameters in carriers and non-carriers of the FTO risk haplotype

Anthropometric and hormonal parameters were compared in carriers of the most risk haplotype CAGA (CAGA/CAGA homozygotes together with TGTT/CAGA heterozygotes) vs. CAGA non-carriers (TGTT homozygotes). Even in a subgroup of 172 lean women the association of the CAGA risk haplotype carriership with a higher BMI was apparent (CAGA carriers $21.7 \pm 1.98 \mathrm{~kg} / \mathrm{m}^{2}$ vs. non-carriers $21.1 \pm 1.94$ $\left.\mathrm{kg} / \mathrm{m}^{2} ; \mathrm{p}=0.038\right)$. However, the CAGA carriers vs. noncarriers did not differ in waist circumference, WHR and percentage of body fat.

We demonstrated that the CAGA-carriers had significantly higher levels of glucose, insulin and C-peptide in the late phase of the oGTT in comparison with CAGA non-carriers. The CAGA carriers had a tendency to increased proinsulin levels at $60^{\text {th }}$ and $180^{\text {th }}$ min of the oGTT. CAGA carriership was also associated with higher growth hormone levels in the fasting state and at $60^{\text {th }} \mathrm{min}$ of the oGTT (Fig. 1). CAGA carriers had significantly lower levels of total cholesterol ( $4.2 \pm 0.81$ vs. $4.5 \pm 0.75 \mathrm{mmol} / \mathrm{l}, \mathrm{p}=0.030)$ and LDL-cholesterol $\quad(2.2 \pm 0.71 \quad$ vs. $\quad 2.4 \pm 0.69 \mathrm{mmol} / \mathrm{l}$, $\mathrm{p}=0.011)$. There were no differences in IGF-1, PRA, glucagon, leptin, HDL-cholesterol, free fatty acids concentrations and their composition. Lean women with and without CAGA haplotype did not differ in beta-cell function (HOMA $F$, insulinogenic index), insulin sensitivity (HOMA R, Matsuda index, Cederholm index) and disposition indices derived from oGTT (data not shown).

\section{Anthropometric and metabolic parameters with respect} to HC administration

In our cohort of women, 77 of them were using the hormonal contraceptives (HC). There was nonsignificant effect of $\mathrm{HC}$ itself on anthropometric parameters. We assume that $\mathrm{HC}$ usage had similar influence on metabolic parameters as risk haplotype carriership (Fig. 2). Women with HC (without respect to FTO haplotype - the distribution of CAGA carriers was similar in subgroups of $\mathrm{HC}$ users and non-users; chi-square test, NS) had higher levels of glucose, insulin and C-peptide in the late phase of the oGTT and had also higher GH levels in response to glucose load. In addition, women with $\mathrm{HC}$ had significantly higher levels of proinsulin in all phases of the oGTT compared to $\mathrm{HC}$ non-users. Regarding the other tested parameters, the $\mathrm{HC}$ usage was also associated with increased triglycerides $\quad(1.05 \pm 0.374$ vs. $0.75 \pm 0.328 \mathrm{mmol} / \mathrm{l}$, $\mathrm{p}<0.001)$ and increased PRA $(0.94 \pm 0.174$ vs. $0.64 \pm 0.076 \mathrm{ng} / \mathrm{ml} * \mathrm{~h}, \mathrm{p}=0.016$ ). The HC influenced neither the insulin secretion nor the insulin sensitivity indices except of Cederholm index which was significantly lower in women using $\mathrm{HC}$ in comparison with non-users $(81.3 \pm 18.15$ vs. $86.4 \pm 19.89 \mathrm{~kg} * 1 / \mathrm{mIU}$, $\mathrm{p}=0.045$ ). In spite of a demonstrated impact of $\mathrm{HC}$ on $\mathrm{GH}$ levels, there was no difference in IGF-1 levels between $\mathrm{HC}$ users and non-users.

The role played by a different composition of contraceptives has not been studied. 

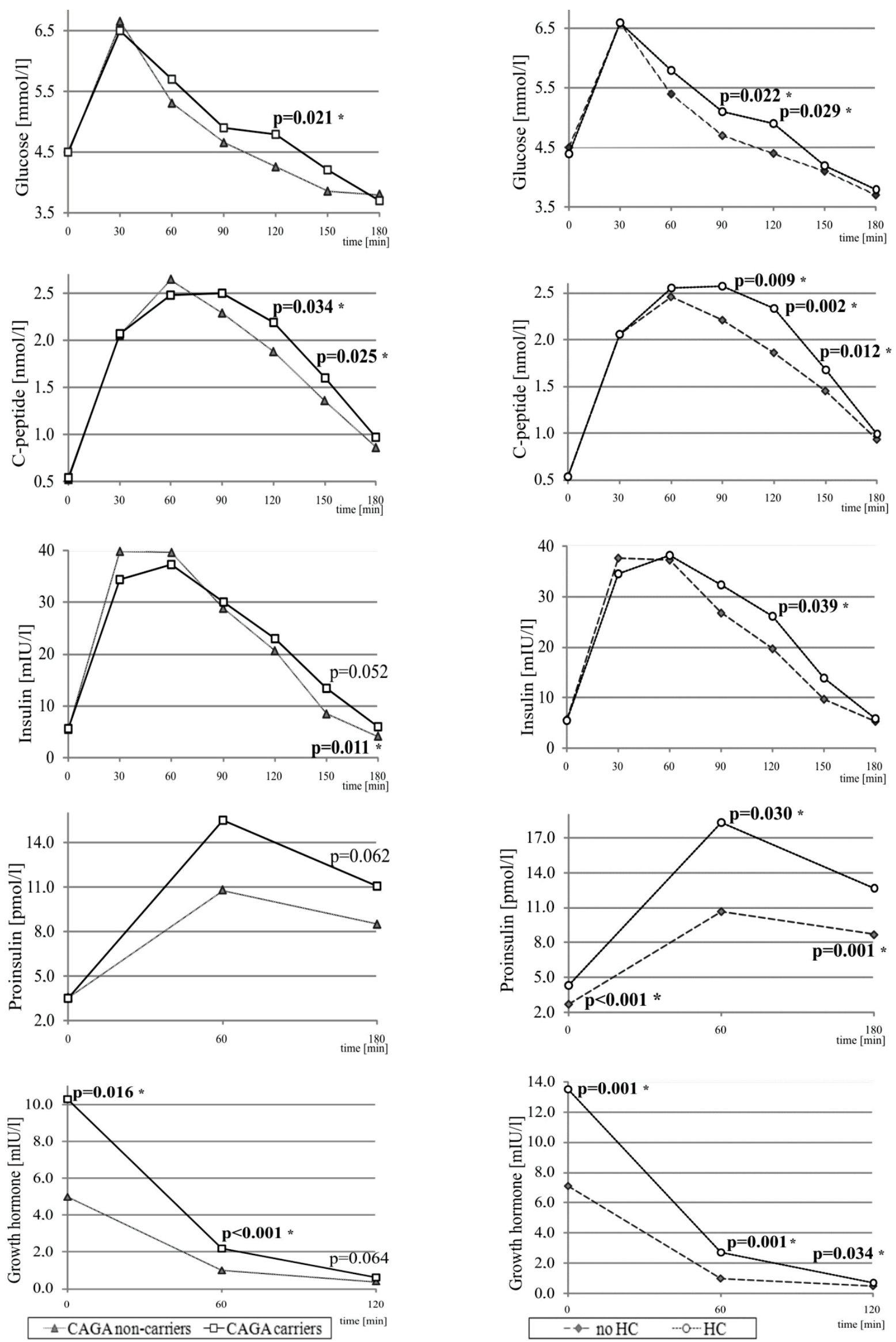

Fig. 1. Metabolic parameters during oGTT in lean women with respect to FTO gene CAGA carriership.

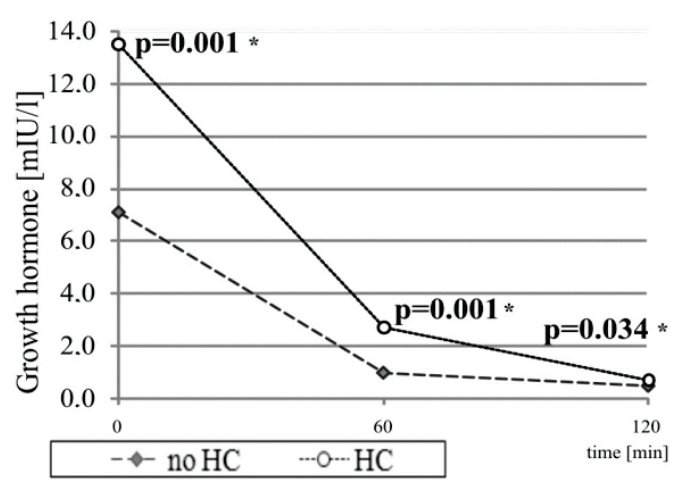

Fig. 2. Metabolic parameters during oGTT in lean women with respect to hormonal contraception $(\mathrm{HC})$ usage. 

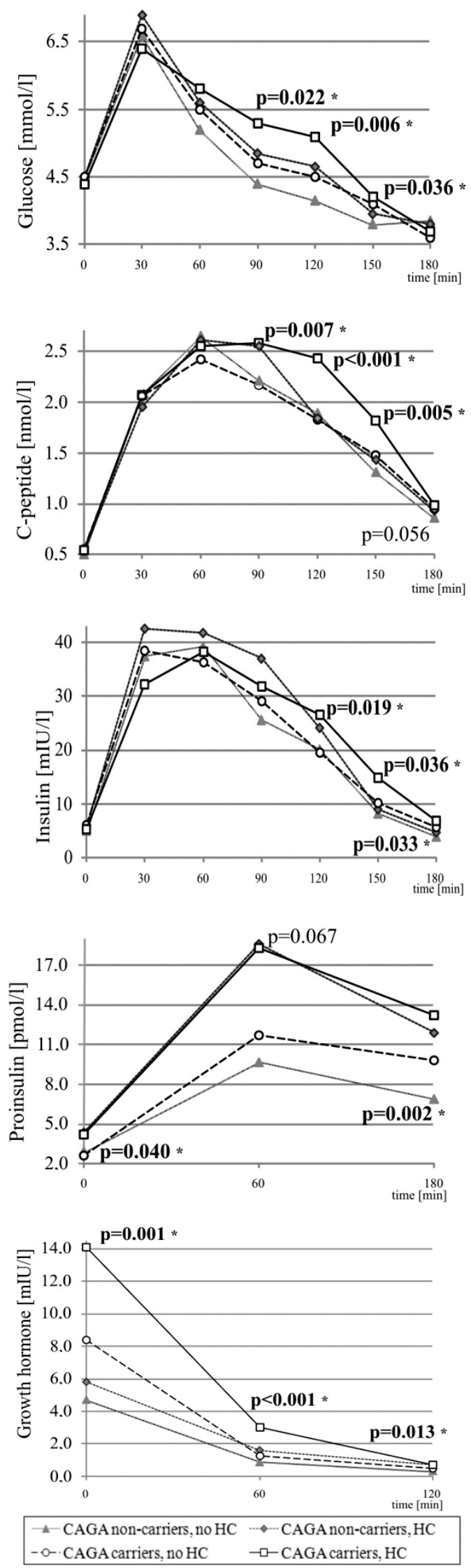

Fig. 3. Metabolic parameters during oGTT in lean women with respect to CAGA carriership and hormonal contraception usage (* statistical significance between CAGA non-carriers without HC and CAGA carriers with $\mathrm{HC}$ ).
Anthropometric and metabolic parameters with respect to FTO gene CAGA carriership and HC usage

The interaction of the risk FTO haplotype carriership and hormonal contraception is shown in Figure 3. The CAGA carriers using $\mathrm{HC}$ had the highest blood glucose, insulin and C-peptide levels in the late phase of oGTT. They also have the highest fasting as well as post glucose load levels of proinsulin and $\mathrm{GH}$ in comparison with the other groups, especially with CAGA non-carriers without $\mathrm{HC}$.

When we assessed the effect of $\mathrm{HC}$ usage in risk-haplotype carriers (Fig. 3, these p levels are not shown there): the HC users had higher level of glucose at $90^{\text {th }}$ and $120^{\text {th }} \min (\mathrm{NS}, \mathrm{p}=0.030)$, C-peptide at $90^{\text {th }}, 120^{\text {th }}$ and $150^{\text {th }} \min (\mathrm{p}=0.040 ; 0.001$ and 0.004$)$ and proinsulin in all phases of the oGTT $(p=0.008$, NS and 0.041) than $\mathrm{HC}$ non-users. Similarly, levels of GH were increased in HC users in all phases of the oGTT ( $p=0.002$ and 0.010 , NS). Nevertheless, no significant effect of $\mathrm{HC}$ was apparent in the subgroup of CAGA non-carriers.

There seems to be an additive effect of riskhaplotype carriership and $\mathrm{HC}$ usage on these metabolic parameters.

\section{Discussion}

Though there have been many published studies that uniformly document the association of FTO gene variants in intron 1 with obesity, the mechanisms by which these variants affect FTO function and how the FTO gene itself contributes to the development of obesity are still not well understood.

The following questions were raised in our study: 1) what are the anthropometric and metabolic consequences of CAGA carriership in lean women, 2 ) could they be influenced by hormonal contraception and 3) how are lean women carrying the obesity risk FTO haplotype protected from obesity?

Association of the risk haplotype with BMI was detected but not with other anthropometric measurements. It confirms the globally observed association of variants in the first intron of FTO gene with increased BMI, which was also reported in the Czech general population (Vcelak et al. 2008, Hubacek et al. 2008, 2009).

In previously published studies genetic variations in the FTO gene were associated not only with increased body weight, but also with other metabolic traits like increased insulin secretion, leptin levels, 
reduced insulin sensitivity and impaired lipid profile. However, these influences on metabolic traits mostly lost their statistical significance after adjustment for the independent effects of obesity (Fall et al. 2013). Our results indicated that even in lean women, the risk CAGA haplotype was associated with increased stimulated glucose, insulin and C-peptide during the late phase of oGTT. Interestingly, CAGA carriership was strongly associated with higher levels of growth hormone (GH) both in the fasting state and in response to glucose load. This is a novel finding regarding metabolic associations of FTO variants. However, Rosskopf et al. (2011) proposed that the GH/IGF-1 axis could be a mediator for the relationship between FTO and BMI.

In fact, increased GH levels could be responsible for the leanness of the studied women carrying the obesity risk CAGA haplotype as well as for the detected metabolic effects found in these women.

$\mathrm{GH}$ is synthesized and secreted by somatotrophic cells in the anterior pituitary. It plays a key role in the control of several complex physiological processes, including growth and metabolism. GH stimulates protein anabolism, enhances fat utilization by enhancing triglyceride breakdown and oxidation in adipocytes. GH has anti-insulin activity; it suppresses the glucose uptake in peripheral tissues and enhances glucose synthesis in the liver. In human obesity, the GH/IGF-1 axis is altered at different levels. Increased adiposity is characterized by blunted GH secretion which is coupled with low, normal or high serum IGF-1 levels (Savastano et al. 2014, Cordoba-Chacon et al. 2015, Pena-Bello et al. 2015). GH fragments as well as the GH-releasing hormone analogue were suggested as possible antiobesity agents (Kokshoorn et al. 2011, Berryman et al. 2013).

We suggest that the elevated beta-cell secretion in the late phase of the oGTT as well as the decreased total- and LDL-cholesterol found in our lean CAGA carriers could be a consequence of increased GH levels in these women (Rudling and Angelin 2001, Weltman et al. 2003, Freathy et al. 2008, Kokshoorn et al. 2011). It could be speculated that the increased GH levels protect women carrying the obesity risk FTO haplotype from the development of obesity (Pena-Bello et al. 2015). The reason of the elevated GH levels in these women is not known. The IGF-1 levels were not elevated in CAGA carriers. The cause of the dissociation of GH/IGF-1 axis is unclear. It could arise from impaired hepatic IGF-1 production (Ho et al. 2003), the role of IGF binding proteins has also to be considered (Ruan and Lai et al. 2010).

A similar finding was obtained in women using hormonal contraception (HC) per se. HC users had elevated GH levels compared to HC non-users but these two groups did not differ in the IGF-1 levels. It has already been published that hormonal contraceptives can modulate the GH/IGF-1-axis by reducing IGF-1 levels and increasing diurnal integrated mean $\mathrm{GH}$ plasma concentrations (Balogh et al. 2000, Ho et al. 2003). In our study, the $\mathrm{HC}$ users did not differ in anthropometric measurements from non-users. In agreement with published findings (Wynn and Doar 1996, Wynn et al. 1996), they had higher levels of triglycerides as well as increased fasting and oGTT stimulated proinsulin and higher late phase glucose, insulin and C-peptide levels, together with modestly impaired insulin sensitivity. Our HC users had increased PRA but without consequent influence on blood pressure.

This study demonstrated for the first time the interaction of FTO genotype with hormonal contraception. HC usage potentiated the influence of CAGA carriership on the metabolic parameters or vice versa (Fig. 3). Our data suggest that the response of proinsulin to glucose load is probably more influenced by $\mathrm{HC}$ than by FTO genotype in contrary to the fasting GH levels where the influence of FTO genotype seems to be more determining than $\mathrm{HC}$ usage (Fig. 3).

In conclusion, we showed an association of FTO risk haplotype CAGA with increased GH levels in lean women which could protect them from obesity. Increased levels of blood glucose, insulin and C-peptide in the late phase of oGTT as well as lower cholesterol and LDLcholesterol could be a metabolic consequence of elevated $\mathrm{GH}$ levels. The $\mathrm{HC}$ usage perse induced similar metabolic effects and the interaction of CAGA haplotype with $\mathrm{HC}$ augmented the impact upon observed biochemical parameters.

The cause of elevated GH levels in lean CAGA carriers as well as a possible role of the FTO gene in the complex regulatory network of hypothalamic $\mathrm{GH}$ secretion should be further elucidated.

\section{Conflict of Interest}

There is no conflict of interest.

\section{Acknowledgements}

We would like to thank all the subjects who participated in this study and all our colleagues for their excellent 
nursing and laboratory assistance. This study was supported by grants IGA MH CZ NT/13544-4 and MH CZ - DRO (Institute of Endocrinology - EU, 00023761) from the Ministry of Health of the Czech Republic.

\section{Abbreviations}

BAI, body adiposity index; BMI, body mass index; DM2, diabetes mellitus type 2; E2V, estradiol-valerate; EE, ethinylestradiol; FTO, fat mass and obesity associated gene; GH, growth hormone; HDL, high-density lipoprotein; HC, hormonal contraceptives; IGF-1, insulinlike growth factor 1; LDL, low-density lipoprotein; OC, oral contraceptives; oGTT, oral glucose tolerance test; PRA, plasma renin activity; PCOS, polycystic ovary syndrome; SNPs, single nucleotide polymorphisms; WHR, waist to hip ratio.

\section{References}

ATTAOUA R, AIT EL MKADEM S, RADIAN S, FICA S, HANZU F, ALBU A, GHEORGHIU M, COCULESCU M, GRIGORESCU F: FTO gene associates to metabolic syndrome in women with polycystic ovary syndrome. Biochem Biophys Res Commun 373: 230-234, 2008.

BALOGH A, KAUF E, VOLLANTH R, GRÄSER G, KLINGER G, OETTEL M: Effects of two oral contraceptives on plasma levels of insulin-like growth factor I (IGF-I) and growth hormone (hGH). Contraception 62: 259-269, 2000.

BARBER TM, BENNETT AJ, GROVES CJ, SOVIO U, RUOKONEN A, MARTIKAINEN H, POUTA A, HARTIKAINEN AL, ELLIOTT P, LINDGREN CM, FREATHY RM, KOCH K, OUWEHAND WH, KARPE F, CONWAY GS, WASS JA, JÄRVELIN MR, FRANKS S, MCCARTHY MI: Association of variants in the fat mass and obesity associated (FTO) gene with polycystic ovary syndrome. Diabetologia 51: 1153-1158, 2008.

BERGMAN RN, STEFANOVSKI D, BUCHANAN TA, SUMNER AE, REYNOLDS JC, SEBRING NG, XIANG AH, WATANABE RM: A better index of body adiposity. Obesity 19: 1083-1089, 2011.

BERRYMAN DE, GLAD CA, LIST EO, JOHANNSSON G: The GH/IGF-1 axis in obesity: pathophysiology and therapeutic considerations. Nat Rev Endocrinol 9: 346-356, 2013.

CEDERHOLM J, WIBELL L: Insulin realease and peripheral sensitivity at the oral glucose tolerance test. Diabetes Res Clin Pract 10: 167-175, 1990.

CORDOBA-CHACON J, MAJUMDAR N, POKALA NK, GAHETE MD, KINEMAN RD: Islet insulin content and release are increased in male mice with elevated endogenous GH and IGF-I, without evidence of systemic insulin resistance or alterations in $\beta$-cell mass. Growth Horm IGF Res 25: 189-195, 2015.

DINA C, MEYRE D, GALLINA S, DURAND E, KÖRNER A, JACOBSON P, CARLSSON LM, KIESS W, VATIN V, LECOEUR C, DELPLANQUE J, VAILLANT E, PATTOU F, RUIZ J, WEILL J, LEVY-MARCHAL C, HORBER F, POTOCZNA N, HERCBERG S, LE STUNFF C, BOUGNÈRES P, KOVACS P, MARRE M, BALKAU B, CAUCHI S, CHÈVRE JC, FROGUEL P: Variation in FTO contributes to childhood obesity and severe adult obesity. Nat Genet 39: 724-726, 2007.

FALL T, HÄGG S, MÄGI R, PLONER A, FISCHER K, HORIKOSHI M, SARIN AP, THORLEIFSSON G, LADENVALL C, KALS M, KUNINGAS M, DRAISMA HH, RIED JS, VAN ZUYDAM NR, HUIKARI V, ET AL; EUROPEAN NETWORK FOR GENETIC AND GENOMIC EPIDEMIOLOGY (ENGAGE) CONSORTIUM: The role of adiposity in cardiometabolic traits: a Mendelian randomization analysis. PLoS Med 10: e1001474, 2013.

FRAYLING TM, TIMPSON NJ, WEEDON MN, ZEGGINI E, FREATHY RM, LINDGREN CM, PERRY JR, ELLIOTT KS, LANGO H, RAYNER NW, SHIELDS B, HARRIES LW, BARRETT JC, ELLARD S, GROVES CJ, KNIGHT B, PATCH AM, NESS AR, EBRAHIM S, LAWLOR DA, RING SM, BENSHLOMO Y, JARVELIN MR, SOVIO U, BENNETT AJ, MELZER D, FERRUCCI L, LOOS RJ, BARROSO I, WAREHAM NJ, KARPE F, OWEN KR, CARDON LR, WALKER M, HITMAN GA, PALMER CN, DONEY AS, MORRIS AD, SMITH GD, HATTERSLEY AT, MCCARTHY MI: A common variant in the FTO gene is associated with body mass index and predisposes to childhood and adult obesity. Science $\mathbf{3 1 6}$ : 889-894, 2007. 
FREATHY RM, TIMPSON NJ, LAWLOR DA, POUTA A, BEN-SHLOMO Y, RUOKONEN A, EBRAHIM S, SHIELDS B, ZEGGINI E, WEEDON MN, LINDGREN CM, LANGO H, MELZER D, FERRUCCI L, PAOLISSO G, NEVILLE MJ, KARPE F, PALMER CN, MORRIS AD, ELLIOTT P, JARVELIN MR, SMITH GD, MCCARTHY MI, HATTERSLEY AT, FRAYLING TM: Common variation in the FTO gene alters diabetes-related metabolic traits to the extent expected given its effect on BMI. Diabetes 57: 1419-1426, 2008.

FREDRIKSSON R, HÄGGLUND M, OLSZEWSKI PK, STEPHANSSON O, JACOBSSON JA, OLSZEWSKA AM, LEVINE AS, LINDBLOM J, SCHIÖTH HB: The obesity gene, FTO, is of ancient origin, up-regulated during food deprivation and expressed in neurons of feeding-related nuclei of the brain. Endocrinology 149: 20622071, 2008.

GERKEN T, GIRARD CA, TUNG YC, WEBBY CJ, SAUDEK V, HEWITSON KS, YEO GS, MCDONOUGH MA, CUNLIFFE S, MCNEILL LA, GALVANOVSKIS J, RORSMAN P, ROBINS P, PRIEUR X, COLL AP, MA M, JOVANOVIC Z, FAROOQI IS, SEDGWICK B, BARROSO I, LINDAHL T, PONTING CP, ASHCROFT FM, O'RAHILLY S, SCHOFIELD CJ: The obesity-associated FTO gene encodes a 2-oxoglutarate-dependent nucleic acid demethylase. Science 318: 1469-1472, 2007.

GRUNNET LG, NILSSON E, LING C, HANSEN T, PEDERSEN O, GROOP L, VAAG A, POULSEN P: Regulation and function of FTO mRNA expression in human skeletal muscle and subcutaneous adipose tissue. Diabetes 58: 2402-2408, 2009.

HO KK, O'SULLIVAN AJ, WOLTHERS T, LEUNG KC: Metabolic effects of oestrogens: impact of the route of administration. Ann Endocrinol 64: 170-177, 2003.

HUBACEK JA, BOHUSLAVOVA R, KUTHANOVA L, KUBINOVA R, PEASEY A, PIKHART H, MARMOT MG, BOBAK M: The FTO gene and obesity in a large Eastern European population sample: the HAPIEE study. Obesity 16: 2764-2766, 2008.

HUBACEK JA, PITHA J, ADAMKOVA V, LANSKA V, POLEDNE R: A common variant in the FTO gene is associated with body mass index in males and postmenopausal females but not in premenopausal females. Czech post-MONICA and 3PMFs studies. Clin Chem Lab Med 47: 387-390, 2009.

KOKSHOORN NE, BIERMASZ NR, ROELFSEMA F, SMIT JW, PEREIRA AM, ROMIJN JA: GH replacement therapy in elderly GH-deficient patients: a systematic review. Eur J Endocrinol 164: 657-665, 2011.

MATSUDA M, DEFRONZO RA: Insulin sensitivity indices obtained from oral glucose tolerance testing: comparison with euglycemic insulin clamp. Diabetes Care 22: 1462-1470, 1999.

MATTHEWS DR, HOSKER JP, RUDENSKI AS, NAYLOR BA, TREACHER DF, TURNER RC: Homeostasis model assessment: insulin resistance and beta-cell function from fasting plasma glucose and insulin concentration in man. Diabetologia 28: 412-419, 1985.

PENA-BELLO L, PERTEGA-DIAZ S, OUTEIRIÑO-BLANCO E, GARCIA-BUELA J, TOVAR S, SANGIAOALVARELLOS S, DIEGUEZ C, CORDIDO F: Effect of oral glucose administration on rebound growth hormone release in normal and obese women: the role of adiposity, insulin sensitivity and ghrelin. PLoS One 10: $\mathrm{e} 0121087,2015$.

ROSSKOPF D, SCHWAHN C, NEUMANN F, BORNHORST A, RIMMBACH C, MISCHKE M, WOLF S, GEISSLER I, KOCHER T, GRABE HJ, NAUCK M, HEBEBRAND J, KROEMER HK, FRIEDRICH N, VÖLZKE H, WALLASCHOFSKI H: The growth hormone-IGF-I axis as a mediator for the association between FTO variants and body mass index: results of the Study of Health in Pomerania. Int J Obes 35: 364-372, 2011.

RUAN W, LAI M: Insulin-like growth fact binding protein: a possible marker for metabolic syndrome? Acta Diabetol 47: 5-14, 2010.

RUDLING M, ANGELIN B: Growth hormone reduces plasma cholesterol in LDL receptor-deficient mice. FASEB $J$ 15: 1350-1356, 2001.

SANCHEZ-PULIDO L, ANDRADE-NAVARRO MA: The FTO (fat mass and obesity associated) gene codes for a novel member of the non-heme dioxygenase superfamily. BMC Biochem 8: 23, 2007.

SAVASTANO S, DI SOMMA C, BARREA L, COLAO A: The complex relationship between obesity and the somatropic axis: the long and winding road. Growth Horm IGF Res 24: 221-226, 2014. 
SCOTT LJ, MOHLKE KL, BONNYCASTLE LL, WILLER CJ, LI Y, DUREN WL, ERDOS MR, STRINGHAM HM, CHINES PS, JACKSON AU, PROKUNINA-OLSSON L, DING CJ, SWIFT AJ, NARISU N, HU T, PRUIM R, XIAO R, LI XY, CONNEELY KN, RIEBOW NL, SPRAU AG, TONG M, WHITE PP, HETRICK KN, BARNHART MW, BARK CW, GOLDSTEIN JL, WATKINS L, XIANG F, SARAMIES J, BUCHANAN TA, WATANABE RM, VALLE TT, KINNUNEN L, ABECASIS GR, PUGH EW, DOHENY KF, BERGMAN RN, TUOMILEHTO J, COLLINS FS, BOEHNKE M: A genome-wide association study of type 2 diabetes in Finns detects multiple susceptibility variants. Science 316: 1341-1345, 2007.

SCUTERI A, SANNA S, CHEN WM, UDA M, ALBAI G, STRAIT J, NAJJAR S, NAGARAJA R, ORRÚ M, USALA G, DEI M, LAI S, MASCHIO A, BUSONERO F, MULAS A, EHRET GB, FINK AA, WEDER AB, COOPER RS, GALAN P, CHAKRAVARTI A, SCHLESSINGER D, CAO A, LAKATTA E, ABECASIS GR: Genome-wide association scan shows genetic variants in the FTO gene are associated with obesity-related traits. PLoS Genet 3: e115, 2007.

TSCHRITTER O, PREISSL H, YOKOYAMA Y, MACHICAO F, HÄRING HU, FRITSCHE A: Variation in the FTO gene locus is associated with cerebrocortical insulin resistance in humans. Diabetologia 50: 2602-2603, 2007.

VCELAK, J, LUKASOVA P, VANKOVA M, VEJRAZKOVA D, KVASNICKOVA H, VRBIKOVA J, VONDRA K, BENDLOVA B: FTO gene is associated not only with obesity-related quantitative traits but also with higher OGTT stimulated glycaemia and leptin levels. Diabetologia 51 (Suppl 1): 326, 2008.

WÅHLÉN K, SJÖLIN E, HOFFSTEDT J: The common rs9939609 gene variant of the fat mass- and obesity-associated gene FTO is related to fat cell lipolysis. J Lipid Res 49: 607-611, 2008.

WELTMAN A, DESPRES JP, CLASEY JL, WELTMAN JY, WIDEMAN L, KANALEY J, PATRIE J, BERGERON J, THORNER MO, BOUCHARD C, HARTMAN ML: Impact of abdominal visceral fat, growth hormone, fitness, and insulin on lipids and lipoproteins in older adults. Metabolism 52: 73-80, 2003.

WYNN V, DOAR J: Some effects of oral contraceptives on carbohydrate metabolism. Lancet 2: 715-719, 1996.

WYNN V, DOAR J, MILLS G: Some effects of oral contraceptives on serum-lipid and lipoprotein levels. Lancet 2: 720-723, 1996. 